\title{
MICROBIAL DIVERSITY OF SPELEOTHEMS IN TWO SOUTHEAST AUSTRALIAN LIMESTONE CAVE ARCHES
}

\author{
David P. Vardeh"1, Jason N. Woodhouse ${ }^{1,2}$, Brett A. Neilan ${ }^{1,3} \mathrm{C}$
}

\begin{abstract}
Peculiar cave structures, nicknamed lobsters, and shaped by drip water, wind, aeolian particles and microbial biofilms, are described from cave entrance arches at Jenolan and Wombeyan caves in southeast Australia. Subaerial biofilms on rock surfaces support complex microbial assemblages adapted to temperature, desiccation, and low irradiance stress. The community composition of active and inactive speleothems was elucidated by next generation sequencing. Active biofilms showed high abundances of cyanobacterial taxa, morphologically and phylogenetically belonging to the genera Chroococcidiopsis and Gloeocapsa, representing an endolithic lifestyle in desiccated and low light conditions. Significant differences were found between caves and between actively accreting and inactive and weathered structures. Functional taxa putatively occupying the same niches were found on active structures in both locations. A temporal succession is proposed, with dominance shifting from Chroococcales to Actinomycetales and highly desiccation-resistant and oligotrophic Rubrobacterales with decreasing water availability.
\end{abstract}

\section{Introduction}

Subaerial biofilms occupy the realm between air and rock surface, which is an ancient and hostile niche. Under favorable conditions, complex and less tolerant eukaryotic taxa, such as algae and fungi, dominate subaerial biofilms. However, under adverse conditions, prokaryotic taxa remain the only microorganisms capable of enduring the extreme environmental conditions characterized by inhospitable habitats like deserts and caves (Gorbushina, 2007). Colonization of a rock substrate is initiated by photosynthetic organisms that enrich the surface and provide a base for heterotrophic taxa (Crispim and Gaylarde, 2005). In subaerial habitats, a constant, close interplay between lithosphere, atmosphere, and colonizing microbes has a direct impact on the biogeochemistry within the biofilm and the underlying minerals (Warscheid and Braams, 2000; Buedel et al., 2004).

The organisms that inhabit subaerial biofilms present on cave structures, are influenced by a series of factors including light availability, the abundance and nature of mineral-enriched drip water, and the physical structure of the rock (Gorbushina, 2007). Substrate micro-topography influences niche availability (Golubic et al., 1981) and colonization speed, with smooth surfaces harder to colonize and favoring small coccoid organisms, such as cyanobacteria of the genus Gloeocapsa. Rougher surfaces with declivities, protecting organisms from wind, solar irradiation, or predation, are colonized faster and provide additional microniches (Miller et al., 2006) resulting in a greater abundance and diversity of organismal shape and metabolism (Gorbushina, 2007).

Cave entrances, as opposed to hypogeal environments, are strongly influenced by surface, physical parameters, including fluctuations in temperature, desiccation and light restriction. The extracellular polymeric substances (EPS) that envelop cell assemblages in microbial mats provide protection from these fluctuations (Kemmling et al., 2004) and govern mineral precipitation (Tourney and Ngwenya, 2009).

Lobster-type speleothems are unique, elongated, narrow structures present within cave entrances, which extend toward the main direction of wind in the cave arch systems (James et al., 1982; Cox et al., 1989b; Lundberg and McFarlane, 2011). Two cave arches in the Blue Mountains area of New South Wales, Australia, are the sites of the first description of this morphology, namely Nettle Cave in Jenolan Karst Conservation Reserve and Victoria Arch in Wombeyan Karst Conservation Reserve (Cox, 1984; James et al., 1982). Their nickname, lobsters or craybacks, originates from the crenulations and elevated ridges across the narrow axis that give the speleothems the appearance of a segmented, crustacean carapace (Cox et al., 1989a). Due to influx of allochthonous matter into the open caves, a plausible explanation for the formation of the lobster ridges is the introduction of particulate irregularities on the surface. Once a particle becomes attached to the surface, it creates a shaded area that phototrophic organisms will avoid, thus causing increased calcification and, ultimately, a ridge in the lighter part (Cox et al., 1989b). The width of the structures is at least partly determined by the height of the cave roof, whereby higher travel distance of the drops from above result in larger splash diameters and wider structures.

Cox and co-workers proposed that the growth of the lobsters is partially biogenic. They also confirmed the presence of Gloeocapsa spp. (Cox et al., 1989b), and Chroococcales have been shown to contribute to calcification in accreted

\footnotetext{
${ }^{1}$ School of Biotechnology and Biomolecular Sciences and the Australian Centre for Astrobiology, University of New South Wales (UNSW), Sydney, Australia

${ }^{2}$ Leibnitz-Institute of Freshwater Ecology and Inland Fisheries

${ }^{3}$ School of Environmental and Life Sciences, University of Newcastle, Australia

c Corresponding author: brett.neilan@newcastle.edu.au
} 
structures, formed by the action of microbes, i.e. microbialites (Saghaï et al., 2015). Extremely little is known about the microbial communities of cave speleothems and there are only a handful of reports worldwide on the peculiar morphology of crayback or lobster stalagmites (Mulec et al., 2007; Lundberg and McFarlane, 2011). Purely physical, carbonate precipitation, driven by evaporation of the water film on the speleothem surface, usually leads to randomly structured precipitate (Hill et al., 1997). In contrast, cyanobacterial photosynthesis induces smooth, laminar precipitation. Seasonality contributes to layering within the structure, with solid or coralline layers deposited in wet seasons and allochthonous layers of dust, grains, and animal matter deposited in dry seasons (Cox et al., 1989b). Decreased, wind-driven evaporation of the scarce water conveys an advantage to organisms settling there (Lundberg and McFarlane, 2011).

Here, we characterize, for the first time, the microbial assemblage, in regard to composition and putative ecological roles, of lobster speleothems in cave arches. We address the extent of any heterogeneity that might occur between sites within a cave system, as well as between cave systems. Also, a sampling regime was enacted to shed light on the succession of microbial communities as speleothems transition from active to the inactive and weathered form over time.

\section{Materials and Methods}

\section{Site description and sampling}

Samples were collected from Nettle Cave (Jenolan Caves, Blue Mountains, NSW, $33.8206^{\circ} \mathrm{S}, 150.0214^{\circ} \mathrm{E}$ ) in March 2013 and from Victoria Arch (Wombeyan Caves, NSW, 34.3167 ${ }^{\circ} \mathrm{S}, 149.9833^{\circ} \mathrm{E}$ ) in April 2013. Nettle Cave is the upper part of an $80 \mathrm{~m}$ high and $40 \mathrm{~m}$ wide tunnel called Devils Coachhouse that runs in a southwest-northeast direction. Almost all speleothems are located on this upper level, which receives light mainly from the smaller, narrow Nettle Cave exit, a roof hole, and to some extent, the large Devils Coachhouse opening (Cox et al., 1989a). Site 1 (sample J1) is an old, weathered and dry lobster (Fig. 1B) with white and flaking surface, and it is about $4 \mathrm{~m}$ away from the walkway to the right. This site, and all other sites, is located about $20 \mathrm{~m}$ from the Nettle cave exit. Site $2(\mathrm{~J} 2$ and J3) is a small blue-green, extremely faint, ridged lobster at the edge of a crevice on the left side of the walkway. It is located directly beneath an old steel cable. Site 3 (Fig. 1A) is a well-ridged speleothem with blue-green surface (J4 and J5), as well as coarse, dry, green sides (J6 and J7). It is located $2 \mathrm{~m}$ behind Site 2. Site 4 (J8 and J9) is an elongate, only faintly blue-green speleothem underneath the walkway in the vicinity of sites 2 and 3 . It was partially removed to allow construction of the walkway. Rock (J10) and soil (J11) samples were collected from between sites.

Victoria Arch at Wombeyan has roughly the same dimensions as Nettle Cave and runs in a north-south direction (Osborne, 1993). As opposed to Nettle Cave, it is at ground level. Site 1 (W1 and W2) is a conspicuous, large (1 $\mathrm{m}$ high) lobster with blue-green coloration $10 \mathrm{~m}$ from the entrance on the left side. Site 2 (W3-W5) is an elongate lobster $12 \mathrm{~m}$ further into the cave and directly to the right of the path. It is ridged and deep blue-green with lightgreen growth on the sides. Site 3 (W6 and W7) is a soft, deep grey-green flowstone, 1 $\mathrm{m}$ high and $3 \mathrm{~m}$ wide and about $10 \mathrm{~m}$ from the opposite cave opening. Site 4 (W8) is a weathered, chipped and white lobster close to site 2. Rock (W9) and soil (W10) samples are adjacent to site 4 . Specimens were drilled to a depth of about $5 \mathrm{~mm}$ using a hand-held, battery-powered drill, equipped with a $20 \mathrm{~mm}$ diamond-coated, circular drill bit which was ethanol-sterilized between samples. Samples were kept at $4{ }^{\circ} \mathrm{C}$ for $1-2$ days in sterile containers prior to DNA extraction. As of 2015, sampling core holes were still clearly visible.

Illuminance at the Jenolan lobster site was previously measured at low values of

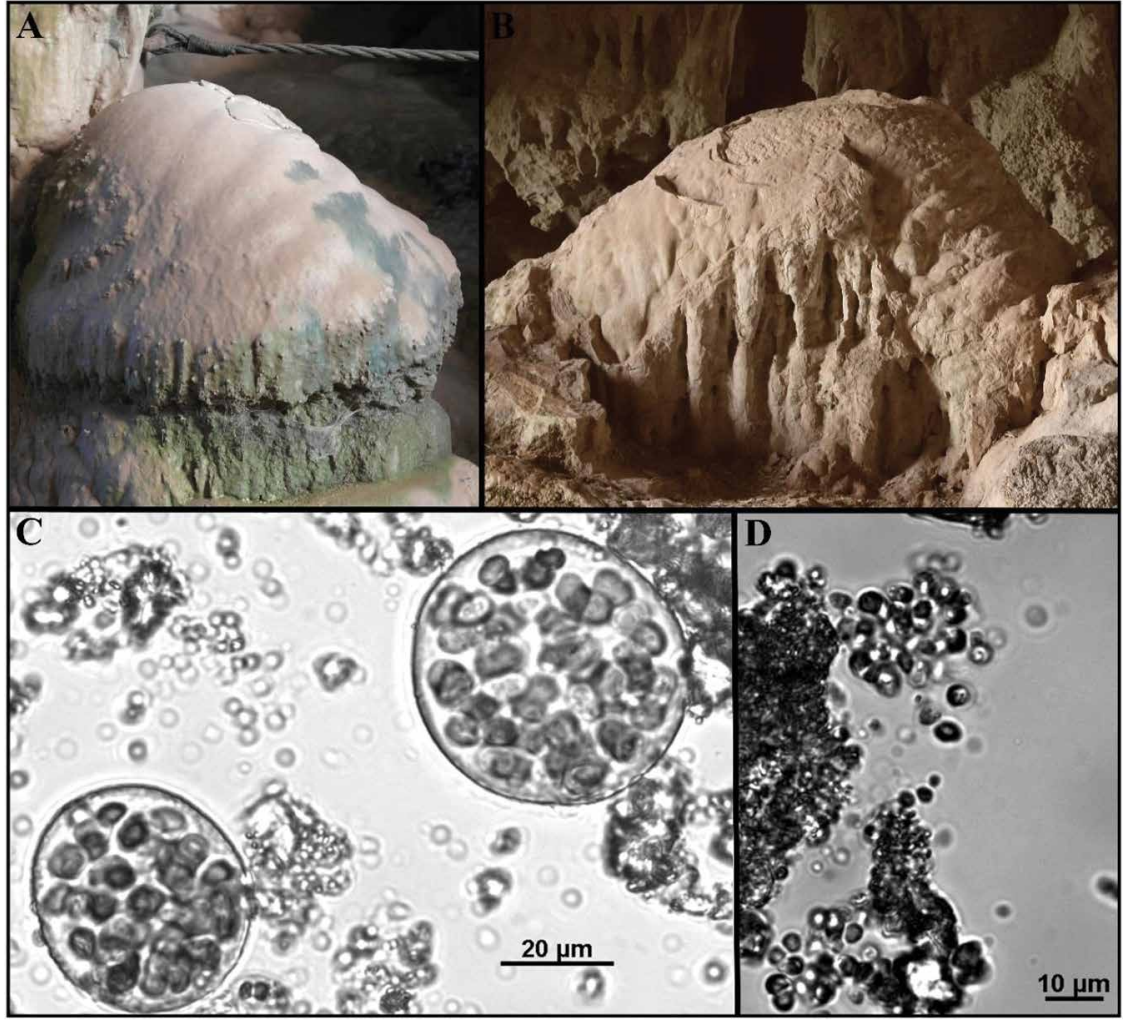

Figure 1. Representative active blue-green (A) and inactive weathered (B) Lobster speleothems from Jenolan Caves and light microscopy pictures of Chroococcidiopsis-Gloeocapsa morphologies with (C) and without (D) gelatinous envelopes. 
50-100 lux on a summer midday, depending on exact location and positioning of the structure (Cox et al. 1989a). No measurements from the Wombeyan site are available, but due to the similarity in cave shape and speleothem positioning, a similar light intensity is presumed. Conditions at Jenolan Caves (792 m above sea level, station number 63036) were unusually wet in the weeks preceding, with February rainfall being registered at about three times the mean for that month (Bureau of Meteorology, 2013a). In contrast, conditions had been unusually dry at Wombeyan Caves (580 m above sea level, station no 63093) before sampling. Only $29.6 \mathrm{~mm}$ of rain fell in the month leading up to the sampling date and March and April were much drier than average (Bureau of Meteorology, 2013b). Both caves are open to the public and receive high numbers of visitors year-round, but most speleothem structures are not directly accessible. As this is an exploratory study covering large sampling areas, small-scale differences in environmental factors are likely, but these will need to be investigated using a narrower approach that includes more physical measurements. Wind, exposure to outside contamination and annual temperature fluctuations are comparable across all samples for the scope of this study. Average monthly temperatures are between $0.5^{\circ} \mathrm{C}$ and $26{ }^{\circ} \mathrm{C}$ in both locations.

\section{DNA extraction, amplification and sequencing}

For each core, 400-500 mg of sample was ground coarsely and sample replicates from the same specimen and the same appearance were pooled. A FastDNA Spin Kit for Soil was used according to manufacturer's instructions (MP Bio). The final buffer was left on the column at $55^{\circ} \mathrm{C}$ to enhance elution and re-centrifuged over the column once to increase yield. DNA was kept at $-20^{\circ} \mathrm{C}$. DNA concentration and quality were measured using a NanoDropTM 1000 Spectrophotometer (Thermo Fisher Scientific). DNA concentrations ranged from 10-40 $\mathrm{ng} \mathrm{hL}^{-1}$ at 260/280-absorbance ratios between 1.59 and 2.02 .

PCR for the V1-V3 region of the 16S rRNA gene was performed using oligonucleotides $27 \mathrm{~F}$ and $519 \mathrm{R}$, each featuring a unique sample specific 8 nt multiplex identifier (MID) tag (Caporaso et al., 2012). A $19.5 \mu \mathrm{L}$ master mix containing $1 \times$ Tris- $\mathrm{HCl}$ buffer (Bioline), $1 \mathrm{mM} \mathrm{MgCl}, 1 \mathrm{mM} \mathrm{BSA}, 1.5 \mathrm{mM}$ dNTPs and $0.3 \cup$ BioTaq DNA Polymerase (Bioline), and 0.1 U Pfu proofreading DNA Polymerase (Promega) was pipetted into a sterile PCR tube along with 50 pmol forward primer, $50 \mathrm{pmol}$ reverse primer, and 5-20 ng of sample DNA. PCR cycling was performed as follows: Initial denaturing for 5 min at $95^{\circ} \mathrm{C}, 30$ cycles of denaturation for $15 \mathrm{~s}$ at $95^{\circ} \mathrm{C}$, annealing for $30 \mathrm{~s}$ at $55^{\circ} \mathrm{C}$, elongation for $60 \mathrm{~s}$ at $68^{\circ} \mathrm{C}$, and a final elongation step for $7 \mathrm{~min}$ at $72^{\circ} \mathrm{C}$. Single-stranded DNA was digested at $37^{\circ} \mathrm{C}$ for 15 min by the addition of $0.05 \mathrm{U}$ Exonuclease I and $0.25 \mathrm{U}$ Shrimp Alkaline Phosphatase (New England Biolabs). The enzymes were inactivated at $80{ }^{\circ} \mathrm{C}$ for $20 \mathrm{~min}$. PCR products $(\sim 530 \mathrm{bp})$ were confirmed by gel electrophoresis on a $1 \%$ agarose gel and then normalised and pooled using a SequalPrep Normalisation Plate (Thermo Fisher Scientific).

Concentration and quality of the pooled library were checked with Qubit and the library size confirmed using the Agilent 2200 TapeStation. The Agencourt AMPure XP bead clean-up kit (Beckman Coulter) was used on the pool to reduce primer dimers. The libraries were sequenced at the Ramaciotti Centre for Genomics, UNSW, Australia, on an Illumina MiSeq instrument using a MiSeq Reagent Kit v3 with a $2 \times 300$ bp run format and default run parameters including adaptor trimming.

\section{Bioinformatic analysis}

Only the 27F-derived sequences were used for taxonomic assignment, as it ensures comparable taxonomic assignment, while reducing an overestimation of operational taxonomic unit (OTU) richness due to progressively deteriorating sequencing quality (Caporaso et al., 2012). The following analysis was performed using the Mothur v. 1.36.0 package (Schloss et al., 2009). Sequence files were trimmed using a scanning window average (window size $=50$, minimum quality score $=30$ ). Sequences that were shorter than $270 \mathrm{bp}$ in length, contained ambiguous bases, or homopolymers of length greater than $8 \mathrm{bp}$ were removed. Unique sequences were aligned with the SILVA database (version 102). Sequences were pre-clustered allowing for a $1 \mathrm{bp}$ mismatch per $100 \mathrm{bp}$ and Uchime, as implemented in Mothur, was used to identify and remove chimeric sequences (Edgar et al., 2011).

Taxonomic annotation was first done with the RDP trainset9_032012 (Cole et al., 2013) reference and lineages, classified as mitochondria, Archaea, Eukarya, or unknown were removed. Sequences classified as chloroplast were retained to ensure that all cyanobacterial sequences were retained. The second taxonomic annotation was done using the GreenGenes 13_8_99 reference file with cut-off 0.8. Subsampling was performed at a level of 9351, consistent with the lowest, observed sampling depth, resulting in 196,371 sequences in total. Of these, 9,508 unique sequences were clustered into OTUs using average neighbor clustering and a distance threshold of 0.03 . Taxonomy of each OTU was assigned using a consensus method and a cut-off of 0.8. A total of 1089 OTUs representing 17,136 sequences could not be classified beyond the level of kingdom.

\section{Phylogenetic analysis}

A phylogenetic tree was constructed by obtaining representatives for each OTU containing at least 10 sequences that annotated to the orders Nostocales or Chroococcales, in addition to any unclassified cyanobacterial sequences. For each OTU representative, the corresponding 519R sequence was recovered and the sequences assembled to form 
$\sim 450$ bp sequences. Reference sequences from NCBI GenBank nucleotide database (accessed June 2015) and OTU sequences were aligned in the BioEdit version 7.2.5. (Hall, 1999) with implementation of the Clustal W (Thompson et al., 1994) multiple alignment algorithm. Phylogenetic inference of the resulting alignment was made with PhyML (Guindon et al., 2010) using a gamma time-reversible model and 1,000 bootstrap replicates. The resulting tree was visualized with Dendroscope version 3.2.10 (Huson and Scornavacca, 2012).

\section{Statistical analysis}

Richness, diversity (inverse Simpson index) and evenness (log-based Shannon index) of the microbial community were calculated from the OTU matrix using Primer 6 (version 6.1.11, Primer-E Ltd., UK). Cluster analysis was performed on a Bray-Curtis similarity resemblance matrix derived from the square root transformed OTU matrix. PERMANOVA was performed using the Primer 6 PERMANOVA+ version 1.0 .1 (http://www.primer-e.com/permanova.htm) add-on using location (Jenolan and Wombeyan caves) and group (Table 1) as fixed factors.

Indicator species analysis was performed to identify OTUs representative of each group using the Indicator Species package in $\mathrm{R}$ (de Cáceres et al., 2010). For inclusion in this analysis, OTUs were required to contribute at least $1 \%$ to the total sequence number in a given sample. A correlation table was constructed featuring each OTU, the site (or sites) that it was an indicator of, the indicator value, and the observed p-value (see Supplementary Table 1). Visualisation of the relationships between indicator OTUs and the morphotypes as an indicator value, edge-weighted, spring-embedded network was performed using Cytoscape version 3.2.1 (http://www.cytoscape.org/index.html).

\section{Results}

\section{Microbial composition of cave entrance subaerial biofilms}

The most abundant taxa found on the active speleothems in Jenolan (groups 2 and 3) were Cyanobacteria $(28.6 \pm 21.3 \%)$, Actinobacteria (25.5 $\pm 10.2 \%)$, unclassified Bacteria $(20.7 \pm 9.7 \%)$, Alphaproteobacteria $(11.8 \pm 9.8$ $\%)$, and Acidobacteria (6.1 $\pm 2.3 \%$ ). The inactive speleothem in Jenolan (group 1) was dominated by Actinobacteria $(69.3 \pm 11.2 \%)$, followed by unclassified Bacteria (10.2 $\pm 9.8 \%)$ and Alphaproteobacteria $(6.4 \pm 2.8 \%)$. The most abundant taxa in active Wombeyan biofilms (groups 6-8) were Acidobacteria (20.2 $\pm 11.4 \%$ ), Actinobacteria (21.3 \pm 8.9 $\%)$, Cyanobacteria (19.1 $\pm 15.8 \%)$, Alphaproteobacteria $(7.3 \pm 4 \%)$, and unclassified Bacteria $(5.5 \pm 2 \%)$. Weathered speleothems and rock controls (group 4) were dominated by Actinobacteria ( $79.9 \pm 2.8 \%$ ), followed by Cyanobacteria (3.1 $\pm 4.4 \%)$, most of which were identified as chloroplasts and Alphaproteobacteria (1.7 $\pm 0.9 \%)$. Soil communities (group 5) contained Actinobacteria (44.3 $\pm 6.5 \%)$, Proteobacteria (27.4 $\pm 1.2 \%)$, unclassified Bacteria ( $3 \pm 1.6 \%)$, and Cyanobacteria $(2 \pm 2.1 \%)$. Of the $14.1 \pm 17.2 \%$ of sequences annotated as belonging to the phylum Cyanobacteria, the major groups were Chroococcales ( $6 \pm 9.4 \%$ ), unclassified Cyanobacteria $(5 \pm 9.5 \%)$, and chloroplast sequences $(2.1 \pm 2.9 \%)$.

Bray-Curtis similarities of square root transformed OTU abundances revealed several distinct groups of samples that are less than $30 \%$ similar to one another (Fig. 2). These groups, consistent with the morphological appearance of the subaerial biofilms, are subsequently annotated as: blue-green mat (two per cave), green mat (Jenolan), grey-green flowstone (Wombeyan), soil controls, and a group containing old inactive speleothems and bare rock controls (shared by both caves, Table 1). Except for one instance, these groups coincided with the respective speleothem specimen from which they were sampled. The exception is sample $\mathrm{J} 3$ from the subsurface layer (ca 2-5 mm) of one active speleothem in Jenolan sharing about $40 \%$ OTU similarity with the cores from site 4 , a pale lobster with only faint hues of blue-green coloration.

Table 1. Groups from Jenolan and Wombeyan samples identified from cluster analysis and morphological description of sampling sites.

\begin{tabular}{ccc}
\hline Samples & Group & Description \\
\hline J3, J8, J9 & 1 & Subsurface sample from blue-green speleothem (J3) and samples from inactive faint blue-green speleothem \\
J2, J4, J5 & 2 & Blue-green speleothem \\
J6, J7 & 3 & Dry green coarse mat on vertical side of group 2 speleothem \\
J1, J10, W8, W9 & 4 & Old weathered speleothems without any visible mat (J1, W8) and bare non-speleothem rock (J10, W9) \\
J11, W10 & 5 & Soil \\
W1, W2 & 6 & Blue-green speleothem at cave entrance \\
W3, W4, W5 & 7 & Blue-green speleothem with some dry green growth \\
W6, W7 & 8 & Green-grey wet soft flowstone \\
\hline
\end{tabular}




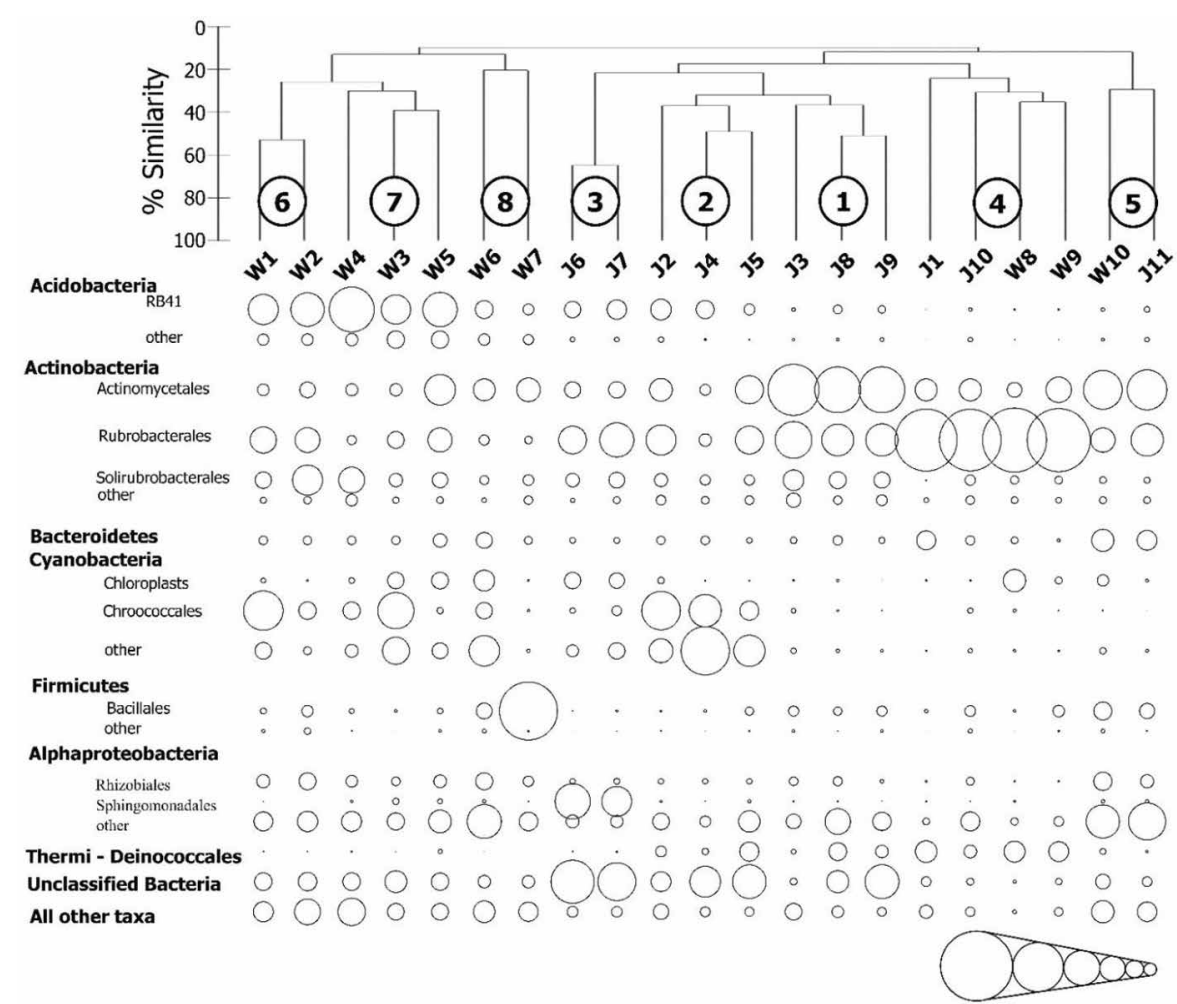

Figure 2. Abundances of the major taxa (contributing $>2 \%$ of total sequences) and clustering of Jenolan and Wombeyan samples into 8 distinct groups. Scale represents $60-$ 40-20-10-5-2.5\% of total abundance. For samples and groups see Table 1.

ty-defined groupings $(p<0.0001, F=18.23)$ and to a lesser extent, morphotype $(p=0.0281, F=3.604)$ on the richness was observed. A significant effect on evenness was observed for Bray-Curtis groupings ( $p=0.0008, F=7.867$ ), but not morphotype $(p=0.0559 F=2.896)$. Pair-wise, the richness of microbial communities associated with subaerial biofilms in the Jenolan Cave entrance was not significantly different from bare rock and inactive speleothems in both caves. The richness of subaerial biofilms in the Wombeyan Cave arch was significantly different from that of the soil control for two of the three structures, namely the two blue-green speleothems, but not the green flowstone. No clear pattern was observed from the differences in evenness within or between caves.

The blue-green and green microbial mats of both Jenolan and Wombeyan caves were distinct from the rock and soil control samples by the presence of abundant cyanobacterial sequences (Fig. 2), consistent with microscopic analysis that confirmed an abundance of Gloeocapsa and Chroococcidiopsis morphotypes. Phylogenetic analysis (Fig. 3) of dominant cyanobacterial 16S rRNA gene sequences indicated the presence of a number of diverse OTUs associated with cultured Chroococcidiopsis and Nostoc species. In addition, a subset of dominant cyanobacterial OTUs were identified that lacked phylogenetically-related, cultured representatives. Cyanobacterial OTUs were shown to vary in their relative contribution to the total sequence count, both within a cave and, more notably, between caves (Fig. 3).

Indicator species analysis of OTUs that contribute at least $1 \%$ to any given samples identified a number of species indicative of the distinct sites, and groups of sites, within each cave system (Fig. 4). A total of 95 indicator OTUs were identified (Supplementary Table 1). Active speleothems were characterized by a range of cyanobacterial OTUs, phylogenetically similar to Chroococcidiopsis and Gloeocapsa, as well as a few chloroplast, Sphingomonas, Rhizobiales, Gemmatimonadetes, and unclassified bacterial OTUs. Acidobacterial OTUs were only indicative of the Wombeyan active structures. One OTU of Cyanobacteria and Solirubrobacterales were indicative of all active structures in both caves. The cyanobacterial genus Acaryochloris was indicative of the coarse, green mat sampled on the side of a Jenolan microbialite. No cyanobacterial indicator was found to be exclusive to rock or soil control sites. Indicator OTUs for the soil samples were Actinomycetales and Gammaproteobacteria.

\section{Discussion}

This study represents the first description of the microbial community composition of subaerial biofilms associated with a unique speleothem structure in cave arches (James et al., 1982; Cox et al., 1989b). Speleothems provide a unique opportunity to study how microbial, meteorological and geographical processes interact to introduce heterogeneity into 


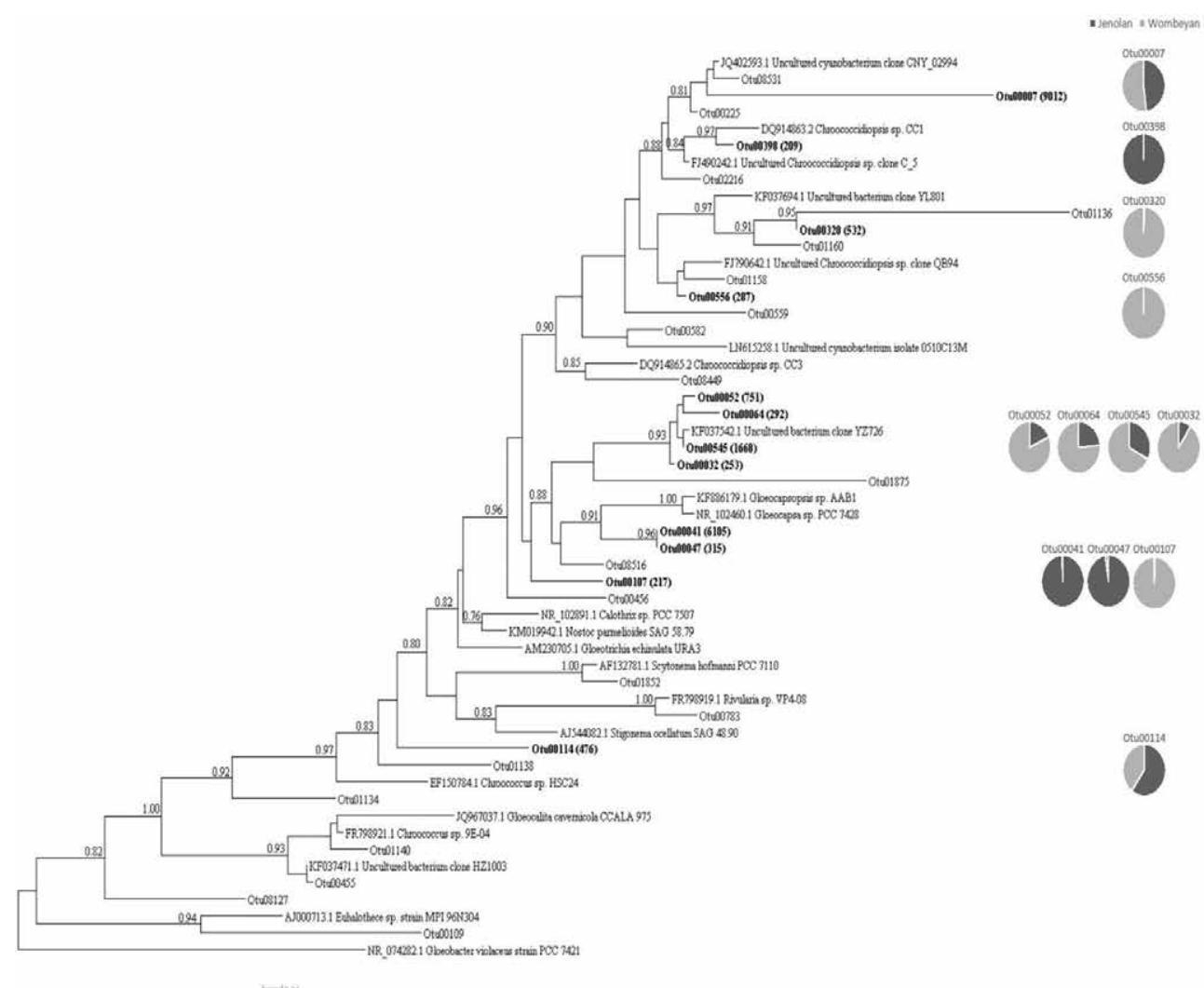

Figure 3. Chroococcales, Nostocales and unclassified cyanobacterial sequences from Jenolan and Wombeyan caves. Only OTUs with more than 10 sequences are included and relative shares of the most abundant OTUs (>200 sequences) are shown as pie charts and absolute sequence numbers are given in parentheses. Scale bar represents 0.01 substitutions per site. landscapes. We sought to gain an understanding of the nature of microorganisms persisting in these biofilms, given the restricted availability of nutrients via drip water and dust. A focus has been placed on cyanobacteria as the main producers of organic matter within these systems, particularly with regards to the specific restrictions placed on this taxon by desiccation and low light.

\section{Differences between and} within caves

Despite significant differences between Jenolan and Wombeyan OTU community composition, no apparent differences in abundance of the major taxa were observed, except for the much higher abundance of Acidobacteria at Wombeyan sites (Fig. 2), suggesting that higher taxa and their respective metabolic and functional niches are represented by similar organisms. In both locations, cyanobacteria of the morphotypes Chroococcidiopsis/Gloeocapsa

were the dominant primary producers and either share OTUs between caves or feature one representative of a putative, functional taxon (Fig. 3). This reflects an extent of functional redundancy to ecological roles and niche-specific adaptations (Yin et al., 2000). Given that the mechanisms of speleothem formation are likely the same in both caves, the key species in initial colonization influences subsequent biofilm growth. No clear pattern of richness, evenness and diversity was found between the caves, indicating that they experience similar environmental conditions and the differences in rainfall before sampling did not result in significant proliferation or decline of certain microbial clades, with the possible exception of an effect on Acidobacteria, discussed below.

Within caves, active blue-green mats were found to host a distinct microbial community compared to the weathered speleothems, bare rock or soil. Indicator OTU analysis showed that Cyanobacteria are indicators of active speleothems only, while Actinobacteria are mainly indicators of inactive structures and bare rock and soil (Fig. 4, Supplementary Table 1). Exceptionally abundant actinobacterial OTUs were distributed throughout the samples and are indicators for several sites, while multiple, less-abundant actinobacterial OTUs are associated with the aforementioned structures and controls. Therefore, a clear distinction in the importance of this taxon exists between active and inactive locations. Cyanobacterial indicators were closely related to the Chroococcales and uncultured species from extreme environments (Pointing et al., 2009; Wong et al., 2010). Jenolan active-site indicators were all cyanobacterial, whereas Wombeyan indicators are phylogenetically more diverse and include Acidobacteria and Sphingomonas OTUs. These taxa are also important constituents of soil and are able to degrade complex organic compounds (Juhasz and Naidu, 2000; Ward et al., 2009). A Gemmatimonadete OTU, indicative of all Wombeyan active mats, while poorly known, is well-adapted to desiccation (DeBruyn et al., 2011).

\section{Low-light, desiccation tolerant Cyanobacteria represent a critical component of speleothem subaerial bio- films}

Cyanobacteria (including chloroplasts) accounted for, on average, $18.6 \%$ of the microbial community of active, speleothem-associated biofilms (Fig. 2). Consistent with their vibrant coloration, this value is likely to underestimate the cyanobacterial contribution to the total biomass in these systems, due to their large cell size. The microscopicallyand phylogenetically-identified order Chroococcales, which includes the low-light adapted Chroococcidiopsis spp. and 




Figure 4. Indicator spring-embedded OTU network of sampled cave sites. Jenolan active and combined control sites in squares, Wombeyan active sites in octagons, OTUs in circles. Circle diameter corresponds to sequence abundance (not the same scale as Fig 2). Soil and rock denote bare cave soil and bare non-speleothem cave rock, respectively.

Gloeocapsa spp., contributed $8.3 \%$ of the total microbial community and were indicators (Fig. 4, Supplementary Table 1) of active biofilms. These findings are consistent with previous reports of biofilms on stone surfaces (Macedo et al., 2009) and caves (Asencio and Aboal, 2000; Lamprinou et al., 2009; Martinez and Asencio, 2010; Popović et al., 2015; Cox, 1984) and the premise that a biofilm established under low-light conditions would be dominated by cyanobacteria (Mulec et al., 2008). The morphotypes found in the cave arches possess thick sheaths (Baqué et al., 2013) and are prolific producers of EPS, which provide labile organic carbon for heterotrophs and offer protection from desiccation (Caiola et al., 1996) and freezing (Knowles and Castenholz, 2008). Production of EPS has also been proposed to support growth of low-light adapted photoautotrophs by facilitating the penetration of photons into deeper layers and minimizing shading of mineral grains and allochthonous particles in caves (Decho et al., 2003).

Low-light tolerance of the Chroococcales enables an endolithic lifestyle that mitigates desiccation stress (Potts, 1999), which is supported by very efficient DNA repair mechanisms conveyed by radiation resistance (Billi et al., 2000). Carbonate, which constitutes the cave speleothems, has high moisture retention and is more translucent than other common rock types and allows for colonization of Chroococcidiopsis (Smith et al., 2014). Retreat of endolithic cyanobacteria into the porous substrate ensures that the organisms receive sufficient water and light, while avoiding desiccation, temperature extremes, competition for space, and predation (Gorbushina, 2007).

It has been proposed that these cyanobacterial species contribute to the formation of cave structures (Cox et al., 1989a), leading to embedding of the biofilm. Several endolithic cyanobacteria have been found to precipitate intracellu- 
lar, carbonate granules, thereby slowing down biomineralization (Benzerara et al., 2014). Decreased burial rate benefits both the primary producers and heterotrophic constituents of the subaerial biofilm. Büedel et al. (2002) proposed a three-story Cyanobacterial biofilm based on endolithic Chroococcidiopsis and Gloeocapsa colonizing crevices and a medial layer of epiliths. The necessity to retain water efficiently makes a similar scaffold in cave biofilms likely, with the majority of the taxa building the understory.

An abundant cyanobacterial OTU related to cultured representatives of the genera Acaryochloris and Loriellopsis was observed in a shaded, vertical section of the Jenolan specimens. Acaryochloris inhabits deep-green, shaded limestone surfaces at Jenolan Caves and the genus is known to possess a red-shifted chlorophyll to facilitate growth at low-light (Behrendt et al., 2015). The branching filamentous Loriellopsis cavernicola has also been described from cave walls (Lamprinou et al., 2011).

\section{Speleothem subaerial biofilms support the growth of oligotrophic microorganisms}

Despite a high abundance of cyanobacteria within the speleothem biofilms, many of the heterotrophic groups resembled oligotrophic, rather than copiotrophic, taxa. Actinobacterial OTUs, similar to those identified from environments such as Roman catacombs (Saarela et al., 2004), lava caves (Hathaway et al., 2014), and granite walls (Laiz et al., 2009) represented the largest proportion of sequences present on both active and inactive speleothems, in accordance with previous reports on stone surfaces (Urzi et al., 2001). The next most common taxa were Acidobacteria and Alphaproteobacteria, both known to be abundant in caves (Schabereiter-Gurtner et al., 2004).

Filamentous Actinobacteria encompassed the family Pseudonocardiaceae, members that have been found to form net-like mycelia on weathered limestone (Cao et al., 2017), providing an advantage for the establishment of biofilms (Scheerer et al., 2009), and the family Geodermatophilaceae, described from a variety of stone surfaces (Urzì et al., 2001). Pseudonocardia is recognized for its capacity to degrade a variety of complex substrates (Reichert et al., 1998). The dominance of Actinomycetes on inactive structures is supported by their growth on recalcitrant organic matter and detrital particles. Geodermatophilaceae have been described from stone surfaces in various climates and are major colonizers of calcareous stone in the Mediterranean (Urzì, 2004). Heavy colonization by Geodermatophilaceae was associated with deterioration of stone surfaces (Urzi et al., 2001) and is potentially the cause for biodegradation at the weathered cave sites.

The presence of dominant OTUs, closely related to the gamma-radiation tolerant Rubrobacter radiotolerans (Yoshinaka et al., 1973), is consistent with the notion that radiation resistance in actinomycetes also conveys a level of desiccation tolerance via an efficient DNA repair mechanism. Tolerance to desiccation results in this group dominating and being indicators of the oldest, and therefore driest, cave structures (Fig. 2, Fig. 4 and Supplementary Table 1). Several OTUs also exhibited relatedness to Rubrobacter bracarensis that was isolated from biodeteriorated granite walls (47).

Most acidobacterial sequences recovered from the cave communities were associated with the taxon RB41 (Fig. 2). Similar sequences have been recovered from lava caves (unpublished), rock surfaces (Yunnan stone forest, China, unpublished), and Antarctic soils (Yergeau et al., 2012). Abundance of this subgroup in soil is negatively correlated to $\mathrm{pH}$ (Jones et al., 2009), but the neutral pH of drip water in Wombeyan caves (McDonald et al., 2007) does not seem to support this finding and nutrient limitation might be the critical factor. Acidobacteria feature inconsistent nutrient utilization and preference patterns even within a subgroup (Naether et al., 2012). Nutrient-limited conditions were found to select for them, signifying their ability to degrade complex carbon sources in an oligotrophic environment (Rasche et al., 2011). Despite Acidobacteria often representing up to $20 \%$ of soil bacterial communities (Janssen, 2006), the origin of this taxon in the Wombeyan Cave structures does not seem to be aeolian. Sequence numbers are very low in the soil and rock controls, which indicates an enrichment on the Wombeyan speleothems rather than passive transport.

Various acidobacterial OTUs were indicators for the blue-green mats and flowstone sites in Wombeyan, but not in Jenolan (Fig. 4, Supplementary Table 1) caves. Acidobacteria have previously been reported in a comparative study of the walls of two caves, where visitor load might explain the differences in abundance (Schabereiter-Gurtner et al., 2004). In the caves, a difference in drip water chemistry is more likely to deter them from one site, but little is known about the physiology and ecology of Acidobacteria to explain this pattern, and without environmental data, it is difficult to understand it.

Most Rhizobiales sequences found were very similar (99-100\%) to sequences of desiccation-tolerant Dichotomicrobium thermohalophilum isolated from a hypersaline lake (Hirsch and Hoffmann, 1989), and the families Bradyrhizobium, Mesorhizobium, and Devosia, from root nodules of various plants (Laranjo et al., 2014). Bradyrhizobium is a major nitrogen fixer and, in symbiosis with algae, provides a valuable service to microbial communities on oligotrophic substrates. Even though Bradyrhizobium was found in all but one cave sample, the relatively high biomass of the microbialite surfaces makes a contaminant origin unlikely.

For most chloroplast and a third of unclassified bacterial sequences, the closest homologue (>91\%) is Prasiolopsis (Trebouxiophyceae), a widely distributed group and a common colonizer of stone surfaces in temperate regions (Rindi 
et al., 2007; Hallmann et al., 2013). Almost all Prasiolopsis-like sequences were accounted for by the dry, green mat (group 3). This taxon forms lichens with fungi, which can stabilize a forming biofilm. It has also been found in dry valleys of Antarctica (de Wever et al., 2009) and on coastal rocks fertilized by bird guano (Heesch et al., 2012). This ability to grow in dry, oligotrophic conditions, where nutrient input is mainly via aerial transport and bird or bat droppings, might explain why this taxon might be prevalent, even though the low similarity to cultured organisms prevents detailed predictions.

\section{Putative successional stages}

The distinct groups observed in the caves are in line with the finding that, as opposed to algae and fungi, no significant spatial structure at the centimeter scale for bacteria can be found (Cutler et al., 2014). Cave locations were sampled at a centimeter to decimeter scale. While active sites have low numbers and roughly equal proportions of Actinomycetales and Rubrobacterales, this proportion shifts drastically in the inactive and weathered speleothems (groups 1 and 4), with almost no cyanobacterial sequences found. The proportion of Actinomycetales to Rubrobacterales shifts from about 2:1 in group 1 to about 1:4 in group 4.

A long-term temporal succession, most likely governed by water availability, may explain this pattern. On active, blue-green structures, where an intact, three-dimensional biofilm is maintained, water can be retained, and extremely desiccation-tolerant species are at much less of an advantage. The roofs of cave arches change over time, when crevices on the surface become clogged and new ones are created. Water availability for speleothems below fluctuates, leading to a shift from Cyanobacteria-driven primary production to a drought-induced collapse of cyanobacterial populations and retreat of coccoid genera such as Chroococcidiopsis and Gloeocapsa into endolithic niches. Oligotrophic Actinobacteria persevere on recalcitrant and complex organic molecules, dead cells, and aeolian particles. When desiccation stress becomes more intense, such as in the weathered speleothems and bare rock samples, only the highly desiccation-resistant Rubrobacterales prevail.

\section{Conclusions}

Significant differences between the microbial communities of speleothem biofilms of two cave arches were found. While rock and soil controls were especially similar between caves and dominated by Actinobacteria, active bluegreen biofilms on speleothems were indicated by endolithic Chroococcidiopsis and Gloeocapsa-like cyanobacteria. Biofilms from both caves harbored similar cyanobacterial representatives, potentially fulfilling the same functions. As a consequence of desiccation-driven progression from active mats to inactive ones and to weathered speleothems, it is proposed that endolithic phototrophs retreat below the surface while oligotrophic Actinomycetes and, later, highly desiccation-resistant Rubrobacterales, dominate the speleothem surface. Inclusion of environmental long-term data would shed light on the dynamics through time, and reasons for distinct community compositions between sites, such as differences in the abundance of Acidobacteria.

\section{Acknowledgements}

This study was supported by the William Macleay Microbiology Research Fund, issued by the Linnean Society of New South Wales. DP Vardeh was supported by a University International Postgraduate Award by UNSW. Acting Managers Dan Cove from Jenolan Caves and David Smith from Wombeyan Caves are gratefully acknowledged for their help with sampling, as is Toby Mills for providing tools. Sampling was conducted under Office of Environment and Heritage (OEH) permit licence SL101114. This project was also supported by the Australian Research Council.

\section{References}

Asencio, A.D., and Aboal, M., 2000, A contribution to knowledge of chasmoendolithic algae in cave-like environments: Algological Studies, v. 98, p. 133-151.

Baqué, M., Viaggiu, E., Scalzi, G., and Billi, D., 2013, Endurance of the endolithic desert cyanobacterium Chroococcidiopsis under UVC radiation: Extremophiles, v. 17, p. 161-169. https://doi.org/10.1007/s00792-012-0505-5.

Behrendt, L., Brejnrod, A., Schliep, M., Sørensen, S.J., Larkum, A.W.D., and Kühl, M., 2015, Chlorophyll f-driven photosynthesis in a cavernous cyanobacterium: The ISME Journal, v. 9, p. 2108-2111. https://doi.org/10.1038/ismej.2015.14.

Benzerara, K., Skouri-Panet, F., Li, J., Férard, C., Gugger, M., Laurent, T., Couradeau, E., Ragon, M., Cosmidis, J., and Menguy, N., 2014, Intracellular Ca-carbonate biomineralization is widespread in cyanobacteria: Proceedings of the National Academy of Sciences, v. 111, p. 10933-10938. https://doi.org/10.1073/pnas.1403510111.

Billi, D., Friedmann, E.I., Hofer, K.G., Caiola, M.G., and Ocampo-Friedmann, R., 2000, lonizing-radiation resistance in the desiccation-tolerant cyanobacterium Chroococcidiopsis: Applied and Environmental Microbiology, v. 66, p. 1489-1492. https://doi.org/10.1128/AEM.66.4.14891492.2000.

Buedel, B., Weber, B., Kuhl, M., Pfanz, H., Sultemeyer, D., and Wessels, D., 2004, Reshaping of sandstone surfaces by cryptoendolithic cyanobacteria: bioalkalization causes chemical weathering in arid landscapes: Geobiology, v. 2, p. 261-268. https://doi.org/10.1128/AEM.66.4.14891492.2000.

Buedel, B., Weber, H.-M., Porembski, S., and Barthlott, W., 2002, Cyanobacteria of inselbergs in the Atlantic rainforest zone of eastern Brazil: Phycologia, v. 41, p. 498-506. https://doi.org/10.2216/i0031-8884-41-5-498.1. 
Bureau of Meteorology, 2013a, http://www.bom.gov.au/jsp/ncc/cdio/weatherData/av?p_nccObsCode=136\&p_display_type=dailyDataFile\&p_ startYear=2013\&p_c=-794902150\&p_stn_num=63036.

Bureau of Meteorology, 2013b, http://www.bom.gov.au/jsp/ncc/cdio/weatherData/av?p_nccObsCode=136\&p_display_type=dailyDataFile\&p_ startYear=2013\&p_c=-796340020\&p_stn_num=63093.

de Cáceres, M., Legendre, P., and Moretti, M., 2010, Improving indicator species analysis by combining groups of sites: Oikos, v. 119, p. 16741684. https://doi.org/10.1111/j.1600-0706.2010.18334.x.

Caiola, M.G., Billi, D., and Friedmann, E.I., 1996, Effect of desiccation on envelopes of the cyanobacterium Chroococcidiopsis sp.(Chroococcales): European Journal of Phycology, v. 31, p. 97-105. https://doi.org/10.1080/09670269600651251a.

Cao, C., Yuan, B., Qin, S., Jiang, J., Tao, F., and Lian, B., 2017, Lentzea pudingi sp. nov., isolated from a weathered limestone sample in a karst area: International Journal of Systematic and Evolutionary Microbiology, v. 67, p. 4873-4878. https://doi.org/10.1099/ijsem.0.002400.

Caporaso, J.G., Lauber, C.L., Walters, W.A., Berg-Lyons, D., Huntley, J., Fierer, N., Owens, S.M., Betley, J., Fraser, L., Bauer, M., Gormley, N., Gilbert, J.A., Smith, G., and Knight, R., 2012, Ultra-high-throughput microbial community analysis on the Illumina HiSeq and MiSeq platforms: ISME Journal, v. 6, p. 1621-1624. https://doi.org/10.1038/ismej.2012.8.

Cole, J.R., Wang, Q., Fish, J.A., Chai, B., McGarrell, D.M., Sun, Y., Brown, C.T., Porras-Alfaro, A., Kuske, C.R., and Tiedje, J.M., 2013, Ribosomal Database Project: Data and tools for high throughput rRNA analysis: Nucleic Acids Research, v. 42, p. D633-D642. https://doi.org/10.1093/ nar/gkt1244.

Cox, G., 1984, Phototrophic stalagmites at Jenolan Caves, NSW: Helictite, v. 22, p. 55-56.

Cox, G., James, J.M., Armstrong, R.A.L., and Leggett, K.E.A., 1989a, Stromatolitic crayfish-like stalagmites: Proceedings of the University of Bristol Spelæological Society, v. 18, p. 339-358.

Cox, G., James, J.M., Leggett, K.E.A., and Osborne, A.L., 1989b, Cyanobacterially deposited speleothems : Subaerial stromatolites: Geomicrobiology Journal, v. 7, p. 245-252. https://doi.org/10.1080/01490458909377870.

Crispim, C.A., and Gaylarde, C.C., 2005, Cyanobacteria and biodeterioration of cultural heritage: A review: Microbial Ecology, v. 49, p. 1-9. https://doi.org/10.1007/s00248-003-1052-5.

Cutler, N.A., Chaput, D.L., Oliver, A.E., and Viles, H.A., 2014, The spatial organization and microbial community structure of an epilithic biofilm: FEMS Microbiology Ecology, v. 91, p. fiu027. https://doi.org/10.1093/femsec/fiu027.

DeBruyn, J.M., Nixon, L.T., Fawaz, M.N., Johnson, A.M., and Radosevich, M., 2011, Global biogeography and quantitative seasonal dynamics of Gemmatimonadetes in soil: Applied and Environmental Microbiology, v. 77, p. 6295-6300. https://doi.org/10.1128/AEM.05005-11.

Decho, A.W., Kawaguchi, T., Allison, M. a., Louchard, E.M., Reid, R.P., Stephens, F.C., Voss, K.J., Wheatcroft, R. a., and Taylor, B.B., 2003, Sediment properties influencing upwelling spectral reflectance signatures: The biofilm gel effect: Limnology and Oceanography, v. 48, p. 431-443. https://doi.org/10.4319/lo.2003.48.1_part_2.0431.

Edgar, R.C., Haas, B.J., Clemente, J.C., Quince, C., and Knight, R., 2011, UCHIME improves sensitivity and speed of chimera detection: Bioinformatics, v. 27, p. 2194-2200. https://doi.org/10.1093/bioinformatics/btr381.

Golubic, S., Friedmann, I., and Schneider, J., 1981, The lithobiontic ecological niche, with special reference to microorganisms: Journal of Sedimentary Research, v. 51, p. 475-478.

Gorbushina, A.A., 2007, Life on the rocks: Environmental Microbiology, v. 9, p. 1613-1631. https://doi.org/10.1111/j.1462-2920.2007.01301.x.

Guindon, S., Dufayard, J.-F., Lefort, V., and Anisimova, M., 2010, New alogrithms and methods to estimate maximum- likelihoods phylogenies: Assessing the performance of PhyML 3.0: Systematic Biology, v. 59, p. 307-321. https://doi.org/10.1093/sysbio/syq010.

Hall, T.A., 1999, BioEdit: A user-friendly biological sequence alignment editor and analysis program for Windows 95/98/NT: Nucleic Acids Symposium Series, v. 41, p. 95-98.

Hallmann, C., Stannek, L., Fritzlar, D., Hause-Reitner, D., Friedl, T., and Hoppert, M., 2013, Molecular diversity of phototrophic biofilms on building stone: FEMS Microbiology Ecology, v. 84, p. 355-372. https://doi.org/10.1111/1574-6941.12065.

Hathaway, J.J.M., Garcia, M.G., Balasch, M.M., Spilde, M.N., Stone, F.D., Dapkevicius, M.D.L.N.E., Amorim, I.R., Gabriel, R., Borges, P.A. V, and Northup, D.E., 2014, Comparison of bacterial diversity in Azorean and Hawai'ian lava cave microbial mats: Geomicrobiology Journal, v. 31, p. 205-220. https://doi.org/10.1080/01490451.2013.777491.

Heesch, S., Sutherland, J.E., and Nelson, W.A., 2012, Marine prasiolales (Trebouxiophyceae, Chlorophyta) from New Zealand and the Balleny Islands, with descriptions of Prasiola novaezelandiae sp. nov. and Rosenvingiella australis sp. nov: Phycologia, v. 51, p. 217-227. https://doi. org/10.2216/10-95.1.

Hill, C.A., Forti, P., and Shaw, T.R., 1997, Cave minerals of the world: National Speleological Society, Huntsville, AL, p. 238.

Hirsch, P., and Hoffmann, B., 1989, Dichotomicrobium thermohalophilum, gen. nov., spec, nov., budding prosthecate bacteria from the Solar Lake (Sinai) and some related strains: Systematic and Applied Microbiology, v. 11, p. 291-301. https://doi.org/10.1016/S07232020(89)80027-X.

Huson, D.H., and Scornavacca, C., 2012, Dendroscope 3: An interactive tool for rooted phylogenetic trees and networks: Systematic Biology, v. 61, p. 1061-1067. https://doi.org/10.1093/sysbio/sys062.

James, J.M., Jennings, J.N., and Dyson, H.G., 1982, Mineral decoration and weathering of the caves: Wombeyan Caves: Sydney Speleological Society, v. 8, p. 121-136.

Janssen, P.H., 2006, Identifying the dominant soil bacterial taxa in libraries of 16 S rRNA and 16S rRNA genes: Applied and Environmental Microbiology, v. 72, p. 1719-1728. http://doi: 10.1128/AEM.72.3.1719.

Jones, R.T., Robeson, M.S., Lauber, C.L., Hamady, M., Knight, R., and Fierer, N., 2009, A comprehensive survey of soil acidobacterial diversity using pyrosequencing and clone library analyses: The ISME Journal, v. 3, p. 442-453. https://doi.org/10.1038/ismej.2008.127.

Juhasz, A.L., and Naidu, R., 2000, Bioremediation of high molecular weight polycyclic aromatic hydrocarbons: a review of the microbial degradation of benzo [a] pyrene: International Biodeterioration and Biodegradation, v. 45, p. 57-88. https://doi.org/10.1016/S0964-8305(00)00052-4.

Kemmling, A., Kämper, M., Flies, C., Schieweck, O., and Hoppert, M., 2004, Biofilms and extracellular matrices on geomaterials: Environmental Geology, v. 46, p. 429-435. https://doi.org/10.1007/s00254-004-1044-x.

Knowles, E.J., and Castenholz, R.W., 2008, Effect of exogenous extracellular polysaccharides on the desiccation and freezing tolerance of rock-inhabiting phototrophic microorganisms: FEMS Microbiology Ecology, v. 66, p. 261-270. https://doi.org/10.1111/j.15746941.2008.00568.x.

Laiz, L., Miller, A.Z., Jurado, V., Akatova, E., Sanchez-Moral, S., Gonzalez, J.M., Dionísio, A., MacEdo, M.F., and Saiz-Jimenez, C., 2009, Isolation of five Rubrobacter strains from biodeteriorated monuments: Naturwissenschaften, v. 96, p. 71-79. https://doi.org/10.1007/s00114-0080452-2. 
Lamprinou, V., Hernández-Mariné, M., Canals, T., Kormas, K., Economou-Amilli, A., and Pantazidou, A., 2011, Morphology and molecular evaluation of Iphinoe spelaeobios gen. nov., sp. nov. and Loriellopsis cavernicola gen. nov., sp. nov., two stigonematalean cyanobacteria from Greek and Spanish caves: International Journal of Systematic and Evolutionary Microbiology, v. 61, p. 2907-2915. https://doi.org/10.1099/ ijs.0.029223-0.

Lamprinou, V., Pantazidou, A., Papadogiannaki, G., Radea, C., and Economou-Amilli, A., 2009, Cyanobacteria and associated invertebrates in Leontari Cave, Attica Greece: Fottea, v. 9, p. 155-164. https://doi.org/10.5507/fot.2009.014.

Laranjo, M., Alexandre, A., and Oliveira, S., 2014, Legume growth-promoting rhizobia: An overview on the Mesorhizobium genus: Microbiological Research, v. 169, p. 2-17. https://doi.org/10.1016/j.micres.2013.09.012.

Lundberg, J., and McFarlane, D.A., 2011, A note on the occurrence of a crayback stalagmite at Niah Caves, Borneo: International Journal of Speleology, v. 40, p. 39-43. https://doi.org/10.5038/1827-806X.40.1.5.

Macedo, M.F., Miller, A.Z., Dionísio, A., and Saiz-Jimenez, C., 2009, Biodiversity of cyanobacteria and green algae on monuments in the Mediterranean Basin: An overview: Microbiology, v. 155, p. 3476-3490. https://doi.org/10.1099/mic.0.032508-0.

Martinez, A., and Asencio, A.D., 2010, Distribution of cyanobacteria at the Gelada Cave (Spain) by physical parameters: Journal of Cave and Karst Studies, v. 72, p. 11-20. https://doi.org/10.4311/jcks2009lsc0082.

McDonald, J., Drysdale, R., Hill, D., Chisari, R., and Wong, H., 2007, The hydrochemical response of cave drip waters to sub-annual and inter-annual climate variability, Wombeyan Caves, SE Australia: Chemical Geology, v. 244, p. 605-623. https://doi.org/10.1016/j.chemgeo.2007.07.007.

Miller, A., Dionísio, A., and Macedo, M.F., 2006, Primary bioreceptivity: A comparative study of different Portuguese lithotypes: International Biodeterioration and Biodegradation, v. 57, p. 136-142. https://doi.org/10.1016/j.ibiod.2006.01.003.

Mulec, J., Kosi, G., and Vrhovsek, D., 2007, Algae promote growth of stalagmites and stalactites in karst caves (Skocjanske Jame, Slovenia): Carbonates and Evaporites, v. 22, p. 6-9. https://doi.org/10.1007/BF03175841.

Mulec, J., Kosi, G., and Vrhovšek, D., 2008, Characterization of cave aerophytic algal communities and effects of irradiance levels on production of pigments: Journal of Cave and Karst Studies, v. 70, p. 3-12.

Naether, A., Foesel, B.U., Naegele, V., Wuest, P.K., Weinert, J., Bonkowski, M., Alt, F., Oelmann, Y., Polle, A., Lohaus, G., Gockel, S., Hemp, A., Kalko, E.K. V, Linsenmair, K.E., et al., 2012, Environmental factors affect acidobacterial communities below the subgroup level in grassland and forest soils: Applied and Environmental Microbiology, v. 78, p. 7398-7406. https://doi.org/10.1128/AEM.01325-12.

Osborne, R., 1993, The history of karstification at Wombeyan Caves, New South Wales, Australia, as revealed by palaeokarst deposits: Cave Science, v. 20, p. 1-8.

Pointing, S.B., Chan, Y., Lacap, D.C., Lau, M.C.Y., Jurgens, J.A., and Farrell, R.L., 2009, Highly specialized microbial diversity in hyper-arid polar desert: Proceedings of the National Academy of Sciences, v. 106, p. 19964-19969. https://doi.org/10.1073/pnas.0908274106.

Popović, S., Subakov Simić, G., Stupar, M., Unković, N., Predojević, D., Jovanović, J., and Ljaljević Grbić, M., 2015, Cyanobacteria, algae and microfungi present in biofilm from Božana Cave (Serbia): International Journal of Speleology, v. 44, p. 141-149. https://doi.org/10.5038/1827806X.44.2.4.

Potts, M., 1999, Mechanisms of desiccation tolerance in cyanobacteria: European Journal of Phycology, v. 34, p. 319-328. https://doi.org/10.108 0/09670269910001736382.

Rasche, F., Knapp, D., Kaiser, C., Koranda, M., Kitzler, B., Zechmeister-Boltenstern, S., Richter, A., and Sessitsch, A., 2011, Seasonality and resource availability control bacterial and archaeal communities in soils of a temperate beech forest: The ISME Journal, v. 5, p. 389-402. https://doi.org/10.1038/ismej.2010.138.

Reichert, K., Lipski, A., Pradella, S., Stackebrandt, E., and Altendorf, K., 1998, Pseudonocardia asaccharolytica sp. nov. and Pseudonocardia sulfidoxydans sp. nov., two new dimethyl disulfide-degrading actinomycetes and emended description of the genus Pseudonocardia: International Journal of Systematic Bacteriology, v. 48, p. 441-449. https://doi.org/10.1099/00207713-48-2-441.

Rindi, F., Mclvor, L., Sherwood, A.R., Friedl, T., Guiry, M.D., and Sheath, R.G., 2007, Molecular phylogeny of the green algal order Prasiolales (Trebouxiophyceae, Chlorophyta): Journal of Phycology, v. 43, p. 811-822. https://doi.org/10.1111/j.1529-8817.2007.00372.x.

Saarela, M., Alakomi, H.-L., Suihko, M.-L., Maunuksela, L., Raaska, L., and Mattila-Sandholm, T., 2004, Heterotrophic microorganisms in air and biofilm samples from Roman catacombs, with special emphasis on actinobacteria and fungi: International Biodeterioration and Biodegradation, v. 54, p. 27-37. https://doi.org/10.1016/j.ibiod.2003.12.003.

Saghaï, A., Zivanovic, Y., Zeyen, N., Moreira, D., Benzerara, K., Deschamps, P., Bertolino, P., Ragon, M., Tavera, R., and López-Archilla, A.I., 2015, Metagenome-based diversity analyses suggest a significant contribution of non-cyanobacterial lineages to carbonate precipitation in modern microbialites: Frontiers in Microbiology, v. 6, p. Article 797. https://doi.org/10.3389/fmicb.2015.00797.

Schabereiter-Gurtner, C., Saiz-Jimenez, C., Piñar, G., Lubitz, W., and Rölleke, S., 2004, Phylogenetic diversity of bacteria associated with Paleolithic paintings and surrounding rock walls in two Spanish caves (Llonín and La Garma): FEMS Microbiology Ecology, v. 47, p. $235-247$. https://doi.org/10.1016/S0168-6496(03)00280-0.

Scheerer, S., Ortega-Morales, O., and Gaylarde, C., 2009, Microbial deterioration of stone monuments-an updated overview: Advances in Applied Microbiology, v. 66, p. 97-139. https://doi.org/10.1016/S0065-2164(08)00805-8.

Schloss, P.D., Westcott, S.L., Ryabin, T., Hall, J.R., Hartmann, M., Hollister, E.B., Lesniewski, R.A., Oakley, B.B., Parks, D.H., and Robinson, C.J., 2009, Introducing mothur: Open-source, platform-independent, community-supported software for describing and comparing microbial communities: Applied and Environmental Microbiology, v. 75, p. 7537-7541. https://doi.org/10.1128/AEM.01541-09.

Smith, H.D., Baqué, M., Duncan, A.G., Lloyd, C.R., McKay, C.P., and Billi, D., 2014, Comparative analysis of cyanobacteria inhabiting rocks with different light transmittance in the Mojave Desert: A Mars terrestrial analogue: International Journal of Astrobiology, v. 13, p. 271-277. https:// doi.org/10.1017/S1473550414000056.

Thompson, J.D., Higgins, D.G., and Gibson, T.J., 1994, CLUSTAL W: Improving the sensitivity of progressive multiple sequence alignment through sequence weighting, position-specific gap penalties and weight matrix choice: Nucleic Acids Research, v. 22, p. 4673-4680. https:// doi.org/10.1093/nar/22.22.4673.

Tourney, J., and Ngwenya, B.T., 2009, Bacterial extracellular polymeric substances (EPS) mediate CaCO3 morphology and polymorphism: Chemical Geology, v. 262, p. 138-146. https://doi.org/10.1016/j.chemgeo.2009.01.006.

Urzì, C., 2004, Microbial deterioration of rocks and marble monuments of the Mediterranean basin: A review: Corrosion Reviews, v. 22, p. 441-458. https://doi.org/10.1515/CORRREV.2004.22.5-6.441.

Urzì, C., Brusetti, L., Salamone, P., Sorlini, C., Stackebrandt, E., and Daffonchio, D., 2001, Biodiversity of Geodermatophilaceae isolated from altered stones and monuments in the Mediterranean basin: Environmental Microbiology, v. 3, p. 471-479. https://doi.org/10.1046/j.14622920.2001.00217.x. 
Ward, N.L., Challacombe, J.F., Janssen, P.H., Henrissat, B., Coutinho, P.M., Wu, M., Xie, G., Haft, D.H., Sait, M., and Badger, J., 2009, Three genomes from the phylum Acidobacteria provide insight into the lifestyles of these microorganisms in soils: Applied and Environmental Microbiology, v. 75, p. 2046-2056. https://doi.org/10.1128/AEM.02294-08.

Warscheid, T., and Braams, J., 2000, Biodeterioration of stone: A review: International Biodeterioration and Biodegradation, v. 46, p. $343-368$. https://doi.org/10.1016/S0964-8305(00)00109-8.

de Wever, A., Leliaert, F., Verleyen, E., Vanormelingen, P., Van der Gucht, K., Hodgson, D. a, Sabbe, K., and Vyverman, W., 2009, Hidden levels of phylodiversity in Antarctic green algae: Further evidence for the existence of glacial refugia: Proceedings of the Royal Society B: Biological Sciences, v. 276, p. 3591-3599. https://doi.org/10.1098/rspb.2009.0994.

Wong, F.K.Y., Lacap, D.C., Lau, M.C.Y., Aitchison, J.C., Cowan, D.A., and Pointing, S.B., 2010, Hypolithic microbial community of quartz pavement in the high-altitude tundra of central Tibet: Microbial Ecology, v. 60, p. 730-739. https://doi.org/10.1007/s00248-010-9653-2.

Yergeau, E., Bokhorst, S., Kang, S., Zhou, J., Greer, C.W., Aerts, R., and Kowalchuk, G.A., 2012, Shifts in soil microorganisms in response to warming are consistent across a range of Antarctic environments: The ISME Journal, v. 6, p. 692-702. https://doi.org/10.1038/ismej.2011.124.

Yin, B., Crowley, D., Sparovek, G., De Melo, W.J., and Borneman, J., 2000, Bacterial functional redundancy along a soil reclamation gradient: Applied and Environmental Microbiology, v. 66, p. 4361-4365. https://doi.org/10.1128/AEM.66.10.4361-4365.2000.

Yoshinaka, T., Yano, K., and Yamaguchi, H., 1973, Isolation of highly radioresistant bacterium, Arthrobacter radiotolerans nov. sp: Agricultural and Biological Chemistry, v. 37, p. 2269-2275. https://doi.org/10.1080/00021369.1973.10861003. 